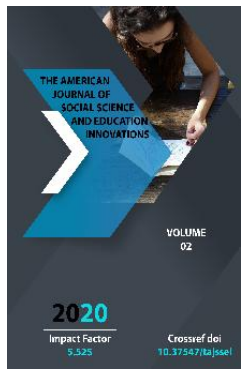

\title{
Thematic Classification Of Onomastic Terms
}

\author{
Nuritdinova Rano Sevdiyevna \\ (Phd) Navoi State Pedagogical Institute, Uzbekistan
}

Journal Website:

http://usajournalshub.c

om/index,php/tajssei

Copyright: Original

content from this work

may be used under the

terms of the creative

commons attributes

4.0 licence.

\section{ABSTRACT}

In linguistics, there are different ways of classifying the lexical richness of a particular language. In particular, classifications such as thematic groups of words, lexical-semantic groups of words, stylistic layers of lexicon, historical-etymological layers of words are widely used. However, in linguistics, it has become a tradition to first divide the nouns in the language into two major groups: common nouns and proper nouns. This classification is limited in size as it refers only to the noun family. In fact, all words (adjectives, rhymes, numbers, verbs, adverbs, adverbs) that do not fall into the category of nouns in the language can be placed as opposites. However, if we approach the issue from this point of view, the lexicon of the language can be divided into two large groups: a group of common (ordinary) nouns and a group of proper nouns. In onomastics, there is also the term appellate, appellate lexicon. The term does not refer to all common words in a language, but to words that are the basis or division of a noun. This means that the appellate lexicon is a branch of cognate words in the language that has the property of transitioning to the function of a pronoun.

\section{KEYWORDS}

Linguistics, lexical-semantic groups of words, common (ordinary) nouns, proper nouns, lexicon, term, onomastics, classification

\section{INTRODUCTION}

Our observations show that onomastics has not yet developed a single and universally accepted classification of proper nouns [1]. This makes it difficult to classify not only names but also onomastic terms. Although some glossaries of onomastic terms have been compiled [2], the terms in this field are still poorly understood as the subject of special scientific research. In Uzbek linguistics, neither side of the problem has been studied. 


\section{MATERIALS AND METHODS}

These cases show that the classification of Uzbek onomastics terminology is a more complex problem. When we were the first to address this issue, we came to the conclusion that the terms of Uzbek onomastics can be classified in several ways:

1. Classifying terms according to which branch of onomastics they belong to.

2. Classifying terms by topic groups.

3. Classifying terms according to their functional activity and inactivity.

4. Classifying terms according to their grammatical structure.

5. Classification of terms by historical and etymological features.

6. Classification of terms according to their association around a particular lexeme, microfield, microgroup, etc.

Now, we define the essence of some of these classifications.

Classifying the terms onomastics according to which branch of onomastics they belong to requires knowledge of the various directions in modern onomastics. This direction, the areas, usually depends on the type of onomastic material in the language. For example, the types of human names are called anthroponyms, the types of place names are called toponyms, and the types of celestial (cosmic) objects are called cosmonyms. The fields of onomastics that study this linguistic material have also emerged, and there are scientific terms that describe them. Accordingly, it can be classified as anthroponymic terms, toponymic terms, cosmonymic terms, zoonomic terms, hydronymic terms, ethnonymic terms. For example, in Uzbek onomastics, a noun, a noun (in the sense of a name), a surname, a patronymic, a nickname, a nickname, a patronymic, a noun, an anthroponym, an anthroponymy, an anthroponymy, a noun, a noun, a historical noun, a noun terms such as nosi, ethnography of names belong to the field of anthroponymy of onomastics.

Some similar specialized terms are also found in the field of toponymy: toponym, toponymy, toponymy of place name, geographical names, topoasos, toponegiz, topoformant, toponymic identifier, toponymization, ethnotoponyms, topotoponyms, toponymic object, toponym meaning, etimon, topolexema, toponymic vocabulary, etc.

It should be noted that the perfection of the classification of the terms onomastics by field depends on the degree to which all its branches in onomastics have developed as a scientific direction. The terms of the developed industries are characterized by a large number and functional activity. For example, the most developed areas of modern Uzbek onomastics are anthroponymy, toponymy, ethnonymy, hydronymics, and their scientific terms form the basis of the terminology of Uzbek onomastics.

The different types of names available in the world's languages may not be equally relevant or characteristic of all national languages. For example, the territory of Uzbekistan is not characterized by swamps, seas and oceans. Therefore, for example, in Uzbek onomastics, the field of limnonymy, which studies the names of swamps, has not developed. Accordingly, the terms limnonyms, limnonymy, limnonymics in the Uzbek language are used only in general in scientific research. 
Our observations also show that a certain part of the fund of onomastic terms is formed in the presence of some functionally active and universal words involved in the formation of the term. In this case, the word, which is functionally universal, comes in a number of terms and creates new terms. It is possible to group such terms around this lexeme. For example, terms formed with the participation of the form ethno (<ethnonym): ethnonym, ethnonym, ethnotoponym, ethnoanthroponym, ethnic nickname, ethnic name, ethnooykonim, ethnic onomastics, ethnoronym, ethnohydronym, ethnodromonym, ethnoindicator, ethnonym, , ethnonymic name, ethnonymization, ethnotermin, ethnonymic type, ethnonymellipsis, ethnoformant.

Terms formed with the participation of the form topo (<toponym), topoanthroponym, topoasos, topoaffix, topogenotsid, topohydronym, topozoonim, topolexema, toponegiz, toponym, toponym-appellate, toponym-archaism, toponymization, toponym, toponym, toponymic tradition, toponymic area, toponymic basis, toponymic term, toponymic sign, toponymic knowledge, toponymic derivative, toponymic lexicon, toponymic isogloss, toponymic object, toponymic classification, toponymization, toponymic system, toponymic, toponym topoethnonym. Such constructions can be seen in a number of lexemes, such as place, noun, anthroponym (anthroponymics), hydro, hydronym (hydronymics).

\section{RESULTS AND DISCUSSIONS}

Our research on the classification of terms has shown that in the classification of terms it is expedient to proceed from the meaning of the term, that is, from the subject expressed in it. This classification fully covers all types and types of onomastic terms, allowing to create a relatively perfect classification of them. Therefore, in this work, the terms of Uzbek onomastics are classified into spiritualthematic groups. They are:

I. Terms denoting scientific directions in the field of onomastics. It is known that any science is divided into certain directions, areas, depending on the subject of study, the nature and type of the object. Due to the nature of the proper noun, which is also studied in onomastics, certain scientific directions have emerged, and they are referred to by certain names - terms. They can be divided into the following groups.

1. The names of scientific disciplines adapted to the study of certain different groups of proper nouns are anthroponymy, toponymy, toponymy, toponomastics, ethnonymy, cosmonymics // astronomy, zoonomics, hydronymics, oronymics, etc.

2. Terms denoting certain branches of the above-mentioned scientific directions: helonimics (the field of studying the famous name of swamps), geonymy (the field of studying the names of any physical-geographical objects), limnonymy (lake). and the field of studying the names of water basins), marsionymy (the field of studying the proper noun of objects on Mars), urbanism (the field of studying the proper noun of objects located in the city), and others.

3. Name of directions of research of onomastic units for the certain purposes: art onomastics, onomapoetics, poetic onomastics, methodical onomastics, folk 
onomastics, poetry onomastics, ethnic onomastics, Uzbek artistic onomastics, onomastics of Uzbek folklore, Onomastics of Uzbek poetry, stylistic onomastics, etc.

4. Terms that define the scientific field from the point of view of history, modernity: modern toponymy, historical onomastics, Uzbek historical nomenclature, modern Uzbek nomenclature, past Uzbek nomenclature.

5. Terms naming the field of onomastics according to the national language and linguistics: Uzbek onomastics, Uzbek nomenclature, Uzbek anthroponymy, Uzbek toponymy, Uzbek theonymy, Uzbek language nomenclature, Uzbek language onomastics, Kyrgyz onomastics, Kazakh onomastics, Karakalpak toponymy, etc.

In some cases, we see that the onomastics of fraternal Turkic languages is generally referred to as Turkic nomenclature, Turkic onomastics, onomastics of Turkic languages.

In the study of onomastics, we find that the field of toponymy is called general toponymy, specific toponymy. In this case, the next term refers to the appearance of toponymy in each linguistics.

6. Terms used to describe researchers in the field of onomastics. This group includes the following terms: nominator // onomast, toponymist // toponymist, Uzbek nomenclature, Uzbek nomenclature scientists, Uzbek toponymists, philologist toponymist, historian toponymist, toponymist scientist, linguist toponymist, onomastics researcher, leading toponymist and $b$.
II. Terms expressing the relationship of the field of onomastics with other disciplines. The emergence and development of proper nouns is associated with many linguistic and nonlinguistic factors. For this reason, the proper noun researcher uses the scientific methods of other disciplines besides linguistics, their achievements, in the analysis of names. This creates a relationship between the field of onomastics and other social and natural sciences. This relationship can be seen in the following terms: toponymy and lexicology, toponymy and etymology, toponymy and dialectology, toponymy and geography, toponymy and lexicography, toponymy and lexicography, toponymy and history, toponymy and cartography, onomastics.

III. Terms common to onomastic analysis methods. Proper nouns differ from other lexical layers of the language by some peculiarities. They develop on the basis of linguistic processes and have a socio-linguistic function. The study of these features allows nominalists to draw some theoretical conclusions, and these theoretical conclusions are called by certain names. There are also some unique aspects to the study of proper nouns. In addition to linguistic methods, nonlinguistic methods common to other disciplines are also used in such research. Such methods of studying the proper noun are also referred to in certain scientific terms, and this category constitutes the scientific methods of studying words.

The terms used to describe the theoretical foundations and methods of scientific analysis in the field of the study of proper nouns can be divided into two groups:

1. Terms common to onomastic theories: scientific or onomastic stage, scientific 
toponymy, onomastic theory, linguistic aspect of onomastics, onomastic direction, onomastic research, onomastic research, systematic criterion, false etymology, principle of restoration of historical names, historical-chronological principle, historical-chronological principle -ethymological direction, methodology of toponymy, toponymic laws, general toponymy.

2. Terms common to the scientific directions of the study of famous names: toponymic policy of the state, ethnography of names, cartographic toponymy, onomastic lexicography, toponymic atlas, toponymic lexicography, toponymic research (s), explanatory dictionary of toponyms, complex study of toponyms, historical-etymological study of toponyms, encyclopedic dictionary of toponyms, etymological dictionary of toponyms, etymological study of toponyms, ethnolinguistic analysis, comparative-geographical research, comparative-linguistic research.

3. Terms common to scientific methods: linguistic classification, non-linguistic classification, linguistic method, linguogeographic method, lexicalsemantic classification, onomastic classification // onomastic classification, synchronous verification, statistical method, stylistic and aesthetic classification; stylistic method, structuraltypological classification, historicalgeographical method, historical method, toponymic classification // toponymic classification, toponymic layer definition, chronological classification, extralinguistic classification, aesthetic classification, comparative-historical method, comparative-modern method.

N.J. Yarashova also studied the methodological aspects of anthroponyms used in children's speech [3].

In addition to the above, there are some terms that are essentially relevant to onomastic research methods and analysis. For example: interpretation, special questionnaires, identification of negativity, onomastic seminar, collection by inquiry, historical toponymic maps, toponymic circles, collection of toponymic wealth, toponymic journal, toponymic illustration, toponymic card index, toponymic dictionary, toponymic information, toponymic passport, toponymic maps, general toponymic map, short toponymic dictionary.

IV. Terms common to the grammatical structure and construction of proper nouns. It is known that proper nouns are created on the basis of linguistic materials available in the language - lexemes and grammatical devices. However, there are some peculiarities in the formation of proper nouns. First of all, not all words in a language can make a noun, the suffixes that make up a noun are at different levels of activity, there are typical models that form a noun, and the structural types of a noun also vary. This shows that the proper noun system has some unique design features. It is the analysis of these features that has led to the emergence of many onomastic terms in onomastics. These are:

1. Terms that describe the composition of a proper noun according to its linguistic material:

a) The noun means the name of the base part: anthroponym appellate, appellate base, appellation name, appellation 
names, appellation toponyms, haptoponyms, hybrid name, hybrid toponym, two-word name, two-stem toponym, zero toponyms, zero co 'index nouns, appellation base of noun, adjective toponyms, rhyming toponyms, verb toponyms, number toponyms, topoasos, word that is the basis of toponym, toponymic base, exclamation toponyms, phytoasos, core or original base, o' anthroponyms with zak morphemes, toponyms with core morphemes;

b) The noun means the name of the auxiliary part: descriptive toponym, anthroponymic formant, original topoformants, affix toponyms, affixed oikonim, affixed toponym, affixless toponym, hydronomic indicator, demunitive suffixes, auxiliary elements, indigenous noun indicator, plural noun indicator, indicator toponyms, indicator words, element at the end of the noun, relative topoformants, nonfunctional suffixes, object-denoting indicator, oikonomic indicators, postpositive component, prepositional component, prefix toponyms, color-quality indicator, number-indicating indicators, topoformant, topoaffixes, toponymic determinant, toponymic indicator, toponymic formant, toponymic element, topoasos, topotherm (indicators), topoformant Uzbek (Turkish) forms, functional indicators, ethnoindicators, ethnoindicative nouns, or ethrinform indicators, additional core, non-slip core, additional toponym, additional toponym, volume indicators, etc.

2. Terms denoting the structural features of a noun: noun composition, noun forms, compound nouns, compound pattern toponyms, compound toponyms, single morpheme nouns, single word toponyms, equivalent conjunctions, sentence pattern toponyms, place name model, pair nouns, pairs of toponyms, pairs of surnames, pairs of names, two-syllable nouns, two-morpheme nouns, two-base toponyms, original form of noun, multi-component toponyms, multimorpheme toponyms, multi-word toponyms , complex toponyms, complex component hydronyms, simple names, simple toponyms, structural models, compound names, toponymic models, toponymic structure, toponym structure, primitive toponyms, artificial toponyms, primitive names, primitive structural names, primitive structural models, etc. 'shma ethnonym, $t$ four component toponyms, t four word toponyms, three basic toponyms, three word toponyms, artificial structural names, abbreviations, abbreviated forms, double $t$ oponyms, compound toponyms, compound nouns, polysemous toponyms, compound ethnonyms, compound ethnonyms, etc.

3. Terms that describe the construction of a noun, that is, the fact that the name is a pseudonym: actually pseudonyms, pseudonyms, hydronomic pseudonyms, plural toponyms, plural toponyms, toponymic pseudonyms, toponyms, pseudonyms, pseudonyms, artificial toponyms, such as common nouns.

4. Terms denoting the method and means of making a proper noun:

a) Terms common to the lexical-semantic method: conversion, internal conversion, external conversion, onomastic conversion, onomastic conversion method, onomastic migration, toponymic 
conversion, transposition, transposition method, functional migration, etc .;

b) Terms common to the morphological method: onomastic suffixes, the possibility of making a toponym of a word, historical artificial nouns, affixal formation of toponyms, transposition (migration), conjunctive nouns, mixed (hybrid) nouns;

c) Terms common to the syntactic method: Terms common to compound nouns: compound noun, Arabic compound anthroponyms, attributive compound toponyms, attributive compound form toponyms, compound nouns based on equal combination of components, nouns based on compound subjunctive components, Mongolian compound anthroponyms , object-compound toponyms, toponyms formed on the basis of predicative compound, toponyms based on predicative relation, syntactically structured ethnonyms, syntactically formed ethnonyms, toponymic component, Persian-Tajik compound toponyms, compound noun components, compound components, such as toponyms that take the form of a compound word;

d) Terms common to isophalic nouns: Arabic isophageal nouns, in fact, isophageal names, isophageal type names, isophalic nouns, isophageal toponyms, isophalic compound nouns, isophalic compound toponyms names.

4. Terms that describe some of the processes in the formation of a proper noun: the law of primary exchange, the law of secondary exchange, the deformation of the name, the reduction of human names, the simplification of toponyms, toponymization, transonimization, transformation, ethnonymization, the process of ethnonymization.

The mentioned classification is limited and does not fully cover the different types of onomastic terms. As this classification, terminological groups are classified according to a universal lexeme.

\section{CONCLUSION}

Our research on the classification of terms has shown that in the classification of terms it is expedient to proceed from the meaning of the term, that is, from the subject expressed in it. This classification fully covers all types and types of onomastic terms, allowing to create a relatively perfect classification of them.

\section{REFERENCES}

1. Begmatov E., Nayimov S. $O$ klassifikatsii toponimov // Tyurkskoe yazykoznanie. - T .: Fan, 1985. - p. 275379.

2. Podolskaya N.V. Dictionary of Russian onomastic terminology. - $M$.: Nauka, 1988.

3. Jumayevna Y. N. Linguo culture logical features of metaphors in children's literature (On the example of khudayberdi tokhtabayev's creative work) // ACADEMICIA: An International Multidisciplinary Research Journal. 2019. - T. 9. - №. 4. - p. 139-145.

4. Ikromova. Gulhida. A. (2020). Developing the speech of primary school pupils through the folklore. ACADEMICIA: An International 
Multidisciplinary Research Journal, 10(5), 567-571.

5. Ярашова, Н. Ж. (2019). ПРОЯВЛЕНИЕ ИНТОНАЦИИ У ДЕТЕЙ ПОСРЕДСТВОМ ОБРАЩЕНИЯ. In Традиции и новации в профессиональной подготовке и деятельности педагога (рр. 128-130).

6. Jumaevna, Y. N. (2020). Occupation of the child's personal mental status in dialogual speech. Asian Journal of Multidimensional Research (AJMR), 9(5), 405-408. 